\title{
Nutrition, Daily Walking and Resilience are Associated with Physical Function in the Oldest Old Men
}

\author{
Jyväkorpi, S. K.
}

2018-11-19

Jyväkorpi , S K , Urtamo , A , Pitkälä , K H \& Strandberg , T E 2018 , ' Nutrition, Daily Walking and Resilience are Associated with Physical Function in the Oldest Old Men ', Journal of nutrition, health \& aging , vol. 22 , no. 10 , pp. 1176-1182 . https://doi.org/10.1007/s12603-018-1136-z

http://hdl.handle.net/10138/292420

https://doi.org/10.1007/s12603-018-1136-z

Downloaded from Helda, University of Helsinki institutional repository.

This is an electronic reprint of the original article.

This reprint may differ from the original in pagination and typographic detail.

Please cite the original version. 


\title{
NUTRITION, DAILY WALKING AND RESILIENCE ARE ASSOCIATED WITH PHYSICAL FUNCTION IN THE OLDEST OLD MEN
}

\author{
S.K. JYVÄKORPI ${ }^{1}$, A. URTAMO ${ }^{1}$, K.H. PITKÄLÄ ${ }^{1}$, T.E. STRANDBERG ${ }^{2}$ \\ 1. University of Helsinki, Department of General Practice and Primary Health Care, and Helsinki University Central Hospital, Unit of Primary Health Care; 2. University of Helsinki, \\ Clinicum, and Helsinki University Hospital, Helsinki, Finland; University of Oulu, Center for Life Course Health Research, Oulu, Finland. Corresponding author: Satu Jyväkorpi, \\ Tukholmankatu 8 B, 00014 University of Helsinki, Finland, Tel: +358 50 4920970, satu.jyvakorpi@gery.fi
}

\begin{abstract}
Background: Maintaining good physical functioning in old age is of utmost importance for healthy and active aging. We examined physical function and associated factors in the oldest-old men. Subjects and methods: The participants of this cross sectional analysis of a longitudinal study were the oldest old men( $n=394$, mean age 88 years, range 82-97 years) from the Helsinki Business Men cohort who responded to a postal health and nutrition survey in 2016. Physical function was defined using the respective subscale (Physical Function, PF) in the RAND-36 health-related quality of life (HRQoL) instrument. Resilience was measured with validated Finnish version of Resilience scale. Diet quality was assessed using Mediterranean diet adherence score (MeDi) and Diet quality index (DQI) which is designed to show adherence to Finnish dietary recommendations. Food and dietary intakes were retrieved using 3-day food records (obtained from a sub-group of the respondents). The participants were divided into quartiles corresponding to their PF scores and health and nutrition indicators were calculated into these PF quartiles. Furthermore, a linear regression model was used to determine factors associated with PF. Results: PF quartiles were positively associated with lower age, daily walking habit, cognition, diet quality, resilience, alcohol use and negatively associated with blood glucose levels, weight loss, body weight (BW) and falls. Polyunsaturated to saturated fat ratio and berry intake were also associated with PF. In a linear regression model PF was positively associated $(\mathrm{p}<.001$, adjusted $\mathrm{R} 2=.560)$ with MeDi, cognition, resilience, vitality (RAND-36), and negatively with age and BW. Conclusion: MeDi, exercise, resilience, cognition, use of alcohol, fat quality and lower age were positively associated with PF in the oldest-old men. Weight loss, falls and interestingly BW were negatively associated with PF.
\end{abstract}

Key words: Physical function, RAND-36, diet quality, Mediterranean diet adherence score, oldest old men.

\section{Introduction}

In longitudinal studies many risk factors of poor physical functioning have been identified. They include, for example, comorbidities, low physical activity, poor nutrition, in particular energy-protein malnutrition, low psychosocial health, social circumstances and lifestyle factors (1-4).

Both obesity in mid-life, low body weight in old age and especially unintentional weight-loss have been associated with frailty and loss of physical function (3-5). While many studies have shown that poor nutritional status, insufficient energy, protein and nutrient intakes along with nutritional deficiencies have been linked to loss of muscle mass and increased risk of frailty, fewer studies have shown how diet quality is associated with physical functioning $(4,6-8)$. In the oldest old men diet quality in relation to physical functioning has not been thoroughly studied.

The population examined in this study differs in many ways from normal population of older people. The participants were the oldest old surviving men from Helsinki Business Men (HBS) cohort which included men from the highest socioeconomic class. The objective of this study was to examine their unique characteristics and to identify factors associated with RAND physical function subscale (PF). We also present a model of the determinants of PF, which considers physical, nutritional and psycho-social factors.

\section{Methods}

The participants of this cross-sectional analysis of a longitudinal study are the surviving oldest old home-dwelling men from The Helsinki Businessmen Study (HBS). It was originally a convenience cohort of executives and businessmen ( $\mathrm{n}=3490$ ) who participated in health check-ups during the 1960s, but since the beginning of the 1970s it has developed into a clinical-epidemiological, longitudinal study (9). No systematic dietary surveys of this cohort have been performed earlier, but in 2016 a postal Health and Nutrition survey was sent to the surviving participants $(n=715)$.

\section{Health survey}

The postal survey included various validated instruments such as RAND-36 Health Related Quality of Life (HRQoL) questionnaire consisting of eight subscales: Physical function (PF), Role limitations caused by physical health problems (Role physical, RP), Role limitations caused by emotional problems (Role emotional, RE), Vitality (VT), Mental health (MH), Social functioning (SF), Bodily pain (BP), and General health (GH) (10). A score of each sub-scale of RAND-36 HRQoL was calculated and compared with the Finnish population data of somewhat younger older men (11). The survey also included validated Finnish version of resilience score (RS-SF), which consists of 14 items from the original Resilience-scale (12). 


\section{THE JOURNAL OF NUTRITION, HEALTH \& AGING@}

The resilience score was calculated summing the 14 items and forming an over-all score (12). Furthermore, the survey included the Clinical Dementia Rating (CDR), of which sum of boxes was calculated, along with various health related questions such as falls, self-reported weight, blood pressure, glucose and cholesterol levels and background information questions (12).

\section{Nutrition}

The nutrition part of the survey included two validated diet quality questionnaires: Mediterranean diet adherence score (MeDi) (14) and Diet Quality Index (DQI) that was originally designed to evaluate the adherence to the Finnish Nutrition Recommendations (15). In addition, the participants received 3-day food diaries and instructions how to complete them. Once the food diaries and diet quality questionnaires were returned, they were checked by a nutritionist and follow-up calls were made in order to verify the quantities and type of food items consumed when necessary. The dietary intake data was analyzed using Nutrica 3.11 program developed for this purpose (16).

\section{Statistical analysis}

The participants were divided into quartiles corresponding to their RAND-36 PF scores and health and nutrition indicators as well as dietary food and nutrition intakes were classified according to the PF quartiles. The statistical significance for hypotheses of linearity was evaluated for a trend with ANOVA for continuous variables or the Mantel-Haenszel test for categorical variables. Furthermore, a linear regression model for associative factors of PF was performed. The statistical analyses were performed, using the SPSS statistical program, version 22 (SPSS IBM, Armonk, NY, USA).

\section{Ethics}

All participants have signed an informed consent to participate in this study. The study protocol was approved by the Helsinki University Central Hospital Ethics Committee.

\section{Results}

Of the surviving participants 476 (response rate 67\%) returned the survey. Of those four participants reported being unable to fill the survey due dementia, nine surveys were returned by respondent's spouse stating that the respondent had recently died, and 69 had other reasons for not filling the survey or they had only partially filled the survey. Finally, 394 of the participants were included in the final analysis, of those 338 filled the diet quality indices and a subgroup of 142 returned 3 -day food records, of which 130 responded both RAND PF-subscale questions and returned food records.
Table 1

RAND-36 HRQoL questionnaire results in HBS cohort compared to general population

\begin{tabular}{lcc}
\hline $\begin{array}{l}\text { RAND- 36 HRQoL } \\
\text { subscales }\end{array}$ & $\begin{array}{c}\text { HBS } \\
\text { Age: 82-97 years } \\
\mathbf{n}=\mathbf{3 9 4}\end{array}$ & $\begin{array}{c}\text { General Finnish } \\
\text { population values (13) } \\
\text { Age: 75-79 years } \\
\mathbf{n}=\mathbf{3 9}\end{array}$ \\
\hline Physical Function (SD) & $59.3(23.6)$ & $54.5(28.2)$ \\
General Health (SD) & $54.8(16.8)$ & $44.7(21.8)$ \\
Mental Health (SD) & $79.9(16.4)$ & $72.8(24.2)$ \\
Vitality (SD) & $74.5(19.8)$ & $55.1(26.8)$ \\
Bodily Pain (SD) & $69.4(27.5)$ & $59.7(27.4)$ \\
$\begin{array}{l}\text { Social Functioning (SD) } \\
\text { Role limitations caused } \\
\text { by phy ic al health }\end{array}$ & $79.5(23.9)$ & $69.4(29.6)$ \\
problems (SD) & $57.2(39.9)$ & $42.1(40.8)$ \\
$\begin{array}{l}\text { Role limitations caused } \\
\text { by emotional problems } \\
\text { (SD) }\end{array}$ & $69.1(37.9)$ & \\
\hline $\begin{array}{l}\text { HRQoL = Health Related Quality of Life; HBS = Helsinki Business Men; SD }= \\
\text { standard deviation }\end{array}$ &
\end{tabular}

The mean age of the participants was 88 years (range 82-97 years). Mean RAND-36 HRQoL scores of the eight subscales are presented in table 1 together with Finnish population based data (13). The scores of our study participants were higher than population means in somewhat younger men (aged 75-79). PF quartiles were positively associated with lower age $(p<0.001)$, daily walking habit $(\mathrm{p}<0.001)$, cognition according to CDR sum of boxes $(\mathrm{p}<0.001)$, both MeDi $(\mathrm{p}=0.009)$ and DQI $(\mathrm{p}=$ $0.004)$, lower blood glucose levels $(\mathrm{p}=0.005)$, alcohol use $(\mathrm{p}=$ $0.012)$ and negatively associated with weight loss $(\mathrm{p}<0.001)$, body weight $(\mathrm{BW})(\mathrm{p}=0.001)$ and falls $(\mathrm{p}<0.001)$ (Table 2$)$.

In a linear regression model (Model 1) PF was associated $(\mathrm{p}<0.001$, adjusted $\mathrm{R} 2=0.56)$ with $\mathrm{MeDi}$, resilience, vitality subscale of RAND-36, cognition (CDR sum of boxes) and negatively with age and BW (Table 3). In model 2 we used the same coefficients but changed MeDi for DQI. In this model DQI did not reach statistical significance $(\mathrm{p}=0.08)$ and the overall model's significance and $\mathrm{R}$ decreased $(\mathrm{p}=0.001$, adjusted $\mathrm{R} 2=0.55$ ).

In a subgroup returning both RAND and dietary records, fat quality (PUFA: SFA-ratio) and berry intake were associated with PF (Table 4). Other foods, energy and nutrient intakes were not associated with PF, although there was a trend of higher intakes of vegetables, legumes, protein, fiber, folate, and vitamin $\mathrm{E}$ with higher PF status.

\section{Discussion}

PF of the oldest old men was linearly associated with diet quality, cognition, daily walking habit, resilience and alcohol use whereas age, blood glucose levels, BW, weight loss and 
NUTRITION, DAILY WALKING AND RESILIENCE ARE ASSOCIATED WITH PHYSICAL FUNCTION

Table 2

Characteristics of the oldest old men in HBS cohort according to RAND-36 HRQoL subscale physical function (PF) quartiles (Q)

\begin{tabular}{|c|c|c|c|c|c|}
\hline $\begin{array}{lc} & \text { Physical function (PF) } \\
\text { Charartiles (Q) } \\
\end{array}$ & $\begin{array}{c}\text { Q1 } \\
\text { PF } \\
\mathrm{n}=94\end{array}$ & $\begin{array}{c}\text { Q2 } \\
\text { PF } \\
\mathrm{n}=94\end{array}$ & $\begin{array}{c}\text { Q3 } \\
\text { PF } \\
\mathrm{n}=97\end{array}$ & $\begin{array}{c}\text { Q4 } \\
\text { PF } \\
\mathrm{n}=98\end{array}$ & p- value ${ }^{1,2}$ \\
\hline PF score & $22.5(10.6)$ & $52.3(6.9)$ & $70.8(4.2)$ & $85.9(5.4)$ & $<.001$ \\
\hline Age, mean (SD) & $89.0(3.8)$ & $87.4(3.5)$ & $86.5(3.2)$ & $87.1(3.6)$ & $<.001$ \\
\hline \multicolumn{6}{|l|}{ Weight loss in last three months, $\%$} \\
\hline $1 .>3 \mathrm{~kg}$ & 11 & 3 & 3 & 3 & $<.001$ \\
\hline 2. Don’t know & 9 & 7 & 4 & 3 & \\
\hline $3.1-3 \mathrm{~kg}$ & 21 & 21 & 11 & 11 & \\
\hline 4. No weight loss & 60 & 68 & 82 & 83 & \\
\hline \multicolumn{6}{|l|}{ Walks every day, $\%$} \\
\hline 1. Not at all & 21 & 1 & 0 & 0 & $<.001$ \\
\hline 2. $<1 \mathrm{~km}$ & 63 & 45 & 26 & 11 & \\
\hline 3. $1-3 \mathrm{~km}$ & 16 & 50 & 63 & 60 & \\
\hline 4. $>3 \mathrm{~km}$ & 0 & 4 & 11 & 30 & \\
\hline \multicolumn{6}{|l|}{ Have you fallen during last year?,\% } \\
\hline 1. Several & 9 & 4 & 1 & 2 & $<.001$ \\
\hline 2. 1-2 times & 50 & 31 & 23 & 16 & \\
\hline 3. I have not fallen & 41 & 64 & 76 & 82 & \\
\hline \multicolumn{6}{|l|}{ Use of alcohol, \% } \\
\hline 1. No alcohol & 24 & 25 & 25 & 18 & .012 \\
\hline 2. Have used before, but stopped & 31 & 17 & 15 & 12 & \\
\hline 3. Use alcohol & 45 & 59 & 60 & 71 & \\
\hline CDR, sum of boxes & $2.3(2.3)$ & $1.4(1.4)$ & $0.7(0.9)$ & $0.5(1.0)$ & $<.001$ \\
\hline Blood glucose & $6.4(1.4)$ & $6.0(.9)$ & $6.1(1.1)$ & $5.7(.6)$ & .005 \\
\hline Cholesterol, $\mathrm{mmol} / \mathrm{l}$ & $4.3(1.0)$ & $4.1(1.0)$ & $4.5(.9)$ & $4.5(1.0)$ & .240 \\
\hline Weight, kg & $79.0(15.2)$ & $79.1(10.5)$ & $77.6(10.0)$ & $73.6(9.0)$ & .001 \\
\hline Mediterranean diet score (SD) & $3.9(1.2)$ & $4.5(1.4)$ & $4.4(1.5)$ & $4.7(2.0)$ & .009 \\
\hline Diet quality index score (SD) & $9.5(1.9)$ & $9.6(1.8)$ & $10.0(1.9)$ & $10.3(1.6)$ & .004 \\
\hline Resilience (RS-14) (SD) & $72.2(13.1)$ & $75.1(10.1)$ & $78.7(7.1)$ & $81.6(10.6)$ & $<.001$ \\
\hline
\end{tabular}

1. Statistical significance of linearity was tested by ANOVA; 2 statistical significance linearity was tested by Mantel-Haenszel test; $\mathrm{HRQoL}=\mathrm{Health}$ related quality of life; $\mathrm{HBS}=\mathrm{Hel}$ inki

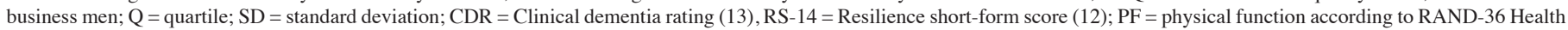
Related Quality of Life instrument.

falls were inversely associated with PF. In linear regression model PF was positively associated with $\mathrm{MeDi}$, age, cognition, RAND-36 vitality part, resilience and negatively with BW.

Our population differs in many ways from the general population. They had higher mean scores of the RAND-36 HRQoL subscales than those of somewhat younger people of the general population (13), which may be explained by their higher socio-economic status (9). Thus, the present participants are a selected group of older men because of survivorship and because the frailest men or ones with poor cognition may have been unable to take part of the survey.

Diet quality, according to MeDi was associated with higher
PF scores. Mediterranean diet has been associated with various health benefits in numerous studies and inversely with frailty (17-18). In our population, MeDi scores in general were quite low, however significantly associated to PF. On the other hand DQI scores were higher which is understandable since DQI is designed to measure adherence to Finnish dietary recommendations and it thus emphasizes foods typically consumed in Finland (bread, milk). However, although this population had low scores on $\mathrm{MeDi}$, in regression model, $\mathrm{MeDi}$ but not DQI was associated with PF showing that the MeDi score is relevant even in this population. This data is consistent with other studies that good nutrition and diet quality play a 
THE JOURNAL OF NUTRITION, HEALTH \& AGINGC

Table 3

Linear regression modes of associative covariates of RAND-36 subscale of physical function (PF)

\begin{tabular}{|c|c|c|c|c|}
\hline Model 1 & $\beta[95 \% \mathrm{CI}]$ unstandardized & $\beta$ standardized coefficents & t- value & Significance \\
\hline \multicolumn{5}{|l|}{ Constant } \\
\hline & $143.21[71.55,233.79]$ & & 3.72 & $<.001$ \\
\hline CDR (sum of boxes) & $-4.75[-7.07,-2.62]$ & -0.28 & -4.30 & $<.001$ \\
\hline Resilience & $0.31[0.03,0.59]$ & 0.13 & 2.17 & .032 \\
\hline MeDi adherence score & $2.77[1.22,4.31]$ & 0.20 & 3.54 & .001 \\
\hline Body weight, $\mathrm{kg}$ & $-0.53[-0.76,-0.29]$ & -0.26 & -4.45 & $<.001$ \\
\hline $\begin{array}{l}\text { Vitality (RAND-36 } \\
\text { HRQoL) }\end{array}$ & $0.48[0.32,0.63]$ & 0.39 & 5.97 & $<.001$ \\
\hline Exercise, hours per week & $0.54[-0.12,1.19]$ & 0.09 & 1.63 & .106 \\
\hline Age & $-1.37[-2.19,-0.56]$ & -0.20 & -3.34 & .001 \\
\hline $\mathrm{R} 2$ & 0.58 & & & \\
\hline Adjusted R2 & 0.56 & & & \\
\hline F-test & 26.56 & & & $<.001$ \\
\hline Std error of the estimate & 14.86 & & & \\
\hline Model 2 & $\beta[95 \%$ CI $]$ unstandardized & $\beta$ standardized coefficents & t- value & Significance \\
\hline Constant & $79.56[51.92,216.25]$ & & 2.55 & .012 \\
\hline CDR (sum of boxes) & $-4.78[-6.88,-2.32]$ & -0.28 & -4.13 & $<.001$ \\
\hline Resilience (RS-14) & $0.39[1.88,9.80]$ & 0.17 & 2.71 & .01 \\
\hline DQI & $1.37[-0.15,2.89]$ & 0.11 & 1.78 & .08 \\
\hline Body Weight & $-0.53[-0.76,-0.28]$ & -0.26 & -4.29 & $<.001$ \\
\hline Vitality (RAND-36) & $0.46[0.30,0.63]$ & 0.37 & 5.52 & $<.001$ \\
\hline Exercise hours per week & $0.63[-0.41,1.31]$ & 0.11 & 1.86 & .07 \\
\hline Age & $-1.35[-2.17,-0.53]$ & -0.20 & -3.26 & .01 \\
\hline $\mathrm{R}^{2}$ & 0.55 & & & \\
\hline Adjusted R2 & 0.53 & & & \\
\hline F-test & 23.76 & & & $<.001$ \\
\hline Std error of the estimate & 15.33 & & & \\
\hline
\end{tabular}

central role in healthy aging and may protect against frailty (1718). Berry intake and fat quality, measured as polyunsaturated to saturated fat-ratio (PUFA:SFA), were associated with higher $\mathrm{PF}$. Cardiovascular disease (CVD) is known to increase frailty and CVD is associated with decline in physical functioning (19). Thus, one could speculate that better fat quality in the oldest-old men may have been a long-term habit which has attributed to lower CVD prevalence. Other dietary food intakes were not associated with PF. There was, however, a trend of higher intake of vegetable, legume, fiber as well as higher protein, folate, and vitamin $\mathrm{E}$ in those with higher $\mathrm{PF}$, which is consistent with earlier studies (6, 17-18).

Alcohol use was associated with higher PF scores in this study. This so called alcohol paradox has also been observed in a prior longitudinal study in this population (20). While high consumption of alcohol has many harmful effects on health, benefits associated with moderate consumption in old age have also been reported (21-22). Especially Mediterranean drinking pattern as well as drinking only with meals have been associated with lower risk of frailty in older adults (22). It has been suggested that moderate alcohol consumption may decrease inflammation associated with frailty (21), but reverse causality cannot be excluded (23).

Surprisingly, lower BW of the participants was associated with higher PF, whereas weight loss was associated with lower PF. In many studies older people have benefitted from higher BMI. However, in a prior study of the same population, constant normal weight was associated with better survival 


\section{NUTRITION, DAILY WALKING AND RESILIENCE ARE ASSOCIATED WITH PHYSICAL FUNCTION}

Table 4

Dietary intakes of foods and nutrients presented as means according to RAND- subscale physical function (PF) quartiles

\begin{tabular}{|c|c|c|c|c|c|}
\hline Foods $\quad \begin{array}{c}\begin{array}{c}\text { Physical function } \\
\text { (PF) quartiles }\end{array} \\
\end{array}$ & $\begin{array}{c}\text { Q1 } \\
\mathbf{P F} \\
\mathbf{n}=\mathbf{2 2}\end{array}$ & $\begin{array}{c}\text { Q2 } \\
\mathbf{P F} \\
\mathbf{n}=\mathbf{3 3}\end{array}$ & $\begin{array}{c}\text { Q3 } \\
\text { PF } \\
\text { n }=38\end{array}$ & $\begin{array}{c}\text { Q4 } \\
\mathbf{P F} \\
\mathbf{n}=37\end{array}$ & p- value ${ }^{1}$ \\
\hline Total fruits and vegetables, $\mathrm{g}(\mathrm{SD})$ & $250(210)$ & $242(122)$ & $245(181)$ & $295(171)$ & .266 \\
\hline Vegetables & $111(113)$ & $123(87)$ & $140(128)$ & $154(97)$ & .106 \\
\hline Fruits & $131(121)$ & $97(84)$ & $87(98)$ & $113(101)$ & .631 \\
\hline Berries & $8(17)$ & $22(33)$ & $17(24)$ & $28(41)$ & .044 \\
\hline $100 \%$ juice & $64(161)$ & $53(89)$ & $30(73)$ & $48(83)$ & .446 \\
\hline Whole grain, g (SD) & $86(55)$ & $82(45)$ & $94(58)$ & $91(57)$ & .512 \\
\hline Nuts, g (SD) & $3(8)$ & $12(36)$ & $7(13)$ & $11(25)$ & .361 \\
\hline Legumes, g (SD) & $5(13)$ & $7(16)$ & $12(29)$ & $15(68)$ & .284 \\
\hline Fish, g (SD) & $32(35)$ & $50(49)$ & $40(49)$ & $56(54)$ & .141 \\
\hline Chicken, g (SD) & $24(34)$ & $24(37)$ & $14(26)$ & $17(29)$ & .230 \\
\hline Red meat, g (SD) & $58(54)$ & $55(62)$ & $67(57)$ & $46(49)$ & .533 \\
\hline Processed meat, g (SD) & $21(26)$ & $26(29)$ & $32(26)$ & $23(20)$ & .733 \\
\hline Milk products, $g(\mathrm{SD})$ & $322(168)$ & $343(196)$ & $306(232)$ & $303(193)$ & .106 \\
\hline Egg, g (SD) & $15(30)$ & $19(27)$ & $7(15)$ & $13(24)$ & .315 \\
\hline \multicolumn{6}{|l|}{ Dietary intake of nutrients } \\
\hline Vitality, kcal (SD) & $1459(418)$ & $1519(374)$ & $1578(456)$ & $1457(349)$ & .985 \\
\hline Protein, g BW/d (SD) & $0.78(0.32)$ & $0.89(0.20)$ & $0.89(0.32)$ & $0.93(0.27)$ & .085 \\
\hline Total fat, g (SD) & $60(21)$ & $65(23)$ & $67(28)$ & $59(19)$ & .717 \\
\hline SFA (SD) & $22(9)$ & $23(9)$ & $23(10)$ & $19(7)$ & .200 \\
\hline MUFA (SD) & $23(8)$ & $23(9)$ & $26(13)$ & $22(9)$ & .920 \\
\hline PUFA (SD) & $10(3)$ & $12(6)$ & $12(6)$ & $12(5)$ & .463 \\
\hline PUFA/SFA ratio & $0.52(0.16)$ & $0.56(0.30)$ & $0.58(0.23)$ & $0.65(0.23)$ & .039 \\
\hline Carbohydrates, g (SD) & $161(27)$ & $161(24)$ & $164(25)$ & $158(22)$ & .879 \\
\hline Sugar, g (SD) & $27(15)$ & $24(17)$ & $26(14)$ & $22(13)$ & .346 \\
\hline Fiber, g (SD) & $19(7)$ & $19(5)$ & $21(9)$ & $21(9)$ & .090 \\
\hline Vitamin $\mathrm{D}, \mu \mathrm{g}(\mathrm{SD})$ & $7(6)$ & $9(6)$ & $7(9)$ & $9(8)$ & .435 \\
\hline Vitamin E, mg (SD) & $9(3)$ & $10(4)$ & $11(5)$ & $11(5)$ & .100 \\
\hline Vitamin $C, m g(S D)$ & $75(66)$ & $79(41)$ & $71(51)$ & $82(49)$ & .737 \\
\hline Folate $\mu \mathrm{g}$ (SD) & $208(66)$ & $228(68)$ & $239(83)$ & $233(71)$ & .203 \\
\hline Thiamine, mg (SD) & $1.0(0.4)$ & $1.0(0.3)$ & $1.0(0.3)$ & $1.1(0.4)$ & .599 \\
\hline Iron, mg (SD) & $9(4)$ & $10(3)$ & $10(3)$ & $10(3)$ & .327 \\
\hline Zinc, mg (SD) & $9(3)$ & $10(2)$ & $11(3)$ & $10(3)$ & .344 \\
\hline Calcium, mg (SD) & $731(323)$ & $848(275)$ & 808 (386) & $744(310)$ & .774 \\
\hline Magnesium, gm (SD) & $273(76)$ & $285(63)$ & $305(90)$ & $301(82)$ & .137 \\
\hline
\end{tabular}

$\mathrm{PF}=$ Physical function; $\mathrm{SD}=$ Standard deviation; PUFA = polyunsaturated fatty acids; SFA = saturated fatty acids; 1 Statistical significance of linearity was tested by ANOVA

and less frailty and disability, whereas weight loss increased all the risks (24). It seems though that constant normal weight throughout life course may be the most beneficial for the PF in this population (24).

In line with prior studies, daily walking was associated with higher PF (25). Frailty increases risk of falls and loss of $\mathrm{PF}$, which was also seen in our data as falls were inversely associated with PF. It is well known that poor cognition increases frailty and loss of physical functioning (26). This is logical since people with poor cognition are often frail and 


\section{THE JOURNAL OF NUTRITION, HEALTH \& AGING@}

declining cognition is linked to depression and poor quality of life compared to people who are cognitively intact (26). Resilience is a relatively less studied health related factor in older people (12). The relationship between resilience and wellbeing has been suggested to be intermediated through positive view of the self, the world and the future (27). In a recent study resilience in older adults was associated with health behaviors such as healthy eating and exercise (28). Furthermore, selfrated successful aging was associated with resilience in another recent study in older people (29). Thus, resilience and attitude of overcoming obstacles in later life may also play a factor in avoiding loss of PF.

\section{Strengths and limitations}

The strength of this study was a relatively high participation of the oldest old men. There are very few studies with such old participants who actively take part in these types of surveys. The same participants have returned surveys many times before, thus this allows us to link this study to earlier findings of the longitudinal data that been gathered for decades of these participants, which increases the reliability of the results. The strength of the nutrition data was that it was gathered using two diet quality indices along with 3-day food records. The nutrition data was checked and verified by a nutritionist and follow-up calls were made in order to check quantities and kind of food items used by the participants in order to ensure the correctness of nutritional data. A major limitation of the study is its' crosssectional design which prevents any conclusions about causal relationships to be drawn. Unfortunately not all participants returned food records. They were only received of a sub-group, thus the number of the food records remained relatively low, which prevented their use in the same analysis with the rest of the data.

\section{Conclusions}

Diet quality, keeping healthy body weight, cognition, resilience, consuming moderate amounts of alcohol, daily walking habit, and avoiding weight loss seem to be very important factors in maintaining good PF in the oldest old men in this study. Even though our population is unique in their characteristics, interventions planned to increase healthy diet, exercise and resilience may promote healthy aging also in general population of older people.

\section{Key points}

- The oldest old men in HBS cohort had higher RAND-36 HRQoL scores than somewhat younger men of general population.

- Diet quality, especially Mediterranean diet adherence score, daily walking, moderate alcohol use, and fat quality were positively associated with RAND-36 HRQoL subscale Physical function (PF) in the oldest old men.

- Body weight, age, blood glucose levels and falls were inversely associated with PF.

- Cognition and resilience were associated with PF

Sources of support: This study was funded by Päivikki and Sakari Sohlberg Foundation and Helsinki University Hospital EVO-funding. The sponsors did not have any role in the study design, analysis or interpretation of data, nor in writing the report or the decision to submit this article. The authors were independent researchers not associated with the funders.

Conflict of Interest: SKJ: reports no conflict of interest; AU: reports no conflict of interest; KHP: reports no conflict of interest; TES: reports having various educational and consultative cooperation with several companies, including Nutricia, Abbott, Amgen, Merck, Pfizer, Novartis, and Novo-Nordisk; a minor amount of stock in Orion Pharma; and is a board member and former president of executive board of European Union Geriatric Medicine Society which has cooperation also with the nutrition industry.

\section{References}

1. Stuck AE, Walthert JM, Nikolaus T, Büla CJ et al. Risk factors for functional statu decline in community-living elderly people: a systematic literature review. Soc Sci Med 1999;48: 445-69.

2. Ayis S, Gooberman-Hill R, Bowling A, Ebrahim S. Predicting catastrophic decline in mobility among older people. Age Ageing 2006;35: 382-87.

3. Morley JE, Argiles JM, Evans WJ, Bhasin S et al. Nutritional Recommendations for the Management of Sarcopenia. J Am Med Dir Assoc 2010;11(6):391-396. doi:10.1016/j.jamda.2010.04.014.

4. Bauer J, Biolo G, Cederholm T, Cesari M et al. Evidence-based recommendation for optimal dietary protein intake in older people: A position paper from the PROTAGE Study Group. J Am Med Dir Assoc 2013;14(8):542 - 559. doi: 10.1016/j. jamda.2013.05.021

5. Strandberg TE, Sirola J, Pitkälä KH et al. Association of midlife obesity and cardiovascular risk with old age frailty: a 26-year follow-up of initially healthy men. Int J Obs 2012;36:1153-1157. doi: 10.1038/ijo.2012.83.

6. Bollwein J, Diekmann R, Kaiser MJ, Bauer JM et al. Dietary quality is related to frailty in community-dwelling older adults. J Gerontol A Biol Sci Med Sci 2013a;68:483-489. doi: 10.1093/gerona/gls204.

7. Bollwein J, Volkert D, Diekmann R, Kaiser MJ et al. Nutritional status according to the mini nutritional assessment (MNA $\left.{ }^{\circledR}\right)$ and frailty in community dwelling older persons: a close relationship. J Nutr Health Aging 2013b;17:351-356. doi: 10.1007/ s12603-013-0009-8.

8. Shikany JM, Barrett-Connor E, Ensrud KE et al. Macronutrients, diet quality, and frailty in older men. J Gerontol A Biol Sci Med Sci 2014;69(6):695-701 . doi: 10.1093/ gerona/glt196.

9. Strandberg TE, Salomaa V, Strandberg AY et al. Cohort Profile: The Helsink Businessmen Study (HBS). Int J Epidemiol 2016;45:1074-1074h. doi: 10.1093/ije/ dyv310

10. Hays RD, Morales LS. The RAND-36 measure of health-related quality of life. Ann Med 2001;33: 350-357.

11. Aalto A-M, Aro AR, Teperi J. RAND-36 Terveyteen liittyvän elämänlaadun mittarina Mittarin luotettavuus ja suomalaiset väestöarvot, Stakes Sosiaali- ja terveysalan tutkimus- ja kehittämiskeskus 1999;Tutkimuksia 101. (in Finnish).

12. Losoi H, Turunen $M$, Wäljäs $M$, Helminen $M$ et al. Psychometric Properties of the Finnish Version of the Resilience Scale and its Short Version. Psychology, Community \& Health 2013;2:1-10.

13. Hughes CP, Berg L, Danziger WL, Coben LA, Martin RL. A new clinical scale for the staging of dementia. Br J Psychiatry 1982;140:566-72.

14. Martinez-Gonzalez MA, Garcia-Arellano A, Toledo E, Salas-Salvado J et al A 14-Item Mediterranean Diet Assessment Tool and Obesity Indexes among High-Risk Subjects: The PREDIMED Trial. Plos One 2012;8: e43134. doi: 10.1371/journal pone.0043134.

15. Mäkelä J, Langström $\mathrm{H}$, Laitinen $\mathrm{K}$. Uusi ruokavalion laadun mittari ravitsemusohjauksen tueksi. Lääkärilehti. 2012;3:161-163d. (in Finnish)

16. Rastas M, Seppänen R, Knuts LR, Karvetti RL, Varo P. Ruokien ravintoainesisältö [Nutrient Composition of Foods]. The Social Insurance Institution of Finland, Turku, 1997.

17. León-Muñoz LM, Guallar-Castillón P, López-García E, Rodríguez-Artalejo F Mediterranean diet and risk of frailty in community-dwelling older adults. J Am Med Dir Assoc 2014:15:899-903. doi: 10.1016/j.jamda.2014.06.013

18. Nowson CA, Service C, Appleton J, Grieger JA. The Impact of Dietary Factors on Indices of Chronic Disease in Older People: A Systematic Review. J Nutr Health Aging 2018;22:282-296. doi: 10.1007/s12603-017-0920-5

19. Bild DE, Fitzpatrick A, Fried LP, Wong ND. Age-related trends in cardiovascula morbidity and physical functioning in the elderly: the Cardiovascular Health Study. J Am Geriatr Soc 1993;41(10):1047-1056.

20. Strandberg AY, Trygg T, Pitkälä KH, Strandberg TE. Alcohol consumption in midlife and old age and risk of frailty: Alcohol paradox in a 30-year follow-up study. Age Ageing 2017;1-7. doi: 10.1093/ageing/afx165.

21. Seematter-Bagnoud L, Spagnoli J, Büla C, Santos-Eggimann B. Alcohol Use and 


\section{NUTRITION, DAILY WALKING AND RESILIENCE ARE ASSOCIATED WITH PHYSICAL FUNCTION}

Frailty in Community-Dwelling Older Persons Aged 65 to 70 Years. J Frailty Aging 2014;3(1):9-14. doi: 10.14283/jfa.2014.2.

22. Ortolá R, García-Esquinas E, León-Muñoz LM, Guallar-Castillón P et al. Patterns of Alcohol Consumption and Risk of Frailty in Community-dwelling Older Adults. J Gerontol A Biol Sci Med Sci 2016;71(2):251-8. doi: 10.1093/gerona/glv125.

23. Shah M, Paulson D. C-reactive protein level partially mediates the relationship between moderate alcohol use and frailty: the Health and Retirement Study. Age Ageing 2016;45(6):874-878. doi: 10.1093/ageing/afw103.

24. Strandberg TE, Stenholm S, Strandberg AY, Salomaa VV et al. The «obesity paradox,» frailty, disability, and mortality in older men: a prospective, longitudinal cohort study. Am J Epidemiol 2013;178(9):1452-60. doi: 10.1093/aje/kwt157.

25. Peterson MJ, Giuliani C, Morey MC et al. Physical activity as a preventative factor for frailty: the health, aging, and body composition study. Health, Aging and Body Composition Study Research Group. J Gerontol A Biol Sci Med Sci 200964:61-68. doi: $10.1093 /$ gerona/gln001.
26. Robertson DA, Savva GM, Kenny RA. Frailty and cognitive impairment--a review of the evidence and causal mechanisms. Ageing Res Rev 2013;12(4):840-851. doi: 10.1016/j.arr.2013.06.004

27. Mak WWS, Ng ISW, Wong CCY. Resilience: Enhancing well-being through the positive cognitive triad. J Couns Psychol 2011;58:610-617.doi 10.1037/a0025195.

28. Clark PG, Greene GW, Blissmer BJ, Lees FD, Riebe DA, Stamm KE. Trajectories of Maintenance and Resilience in Healthful Eating and Exercise Behaviors in Older Adults. J Aging Health. 2017; doi: 10.1177/0898264317746264

29. Jeste DV, Savla GN, Thompson WK, Vahia IV, Glorioso DK, Martin AS et al. Association between older age and more successful aging: critical role of resilience and depression. Am J Psychiatry 2013;170(2):188-96. doi: 10.1176/appi. ajp.2012.12030386 